\title{
Helicogloea globispora sp. nov. from Taiwan
}

\author{
SHENG-HUA WU and ZUEI-CHING CHEN
}

WU, S.-H. \& CHEN, Z.-C.: Helicogloea globispora sp. nov. from Taiwan. - Karstenia 40: 195-196. Helsinki. ISSN 0453-3402.

Helicogloea globispora Sheng H. Wu \& Z.C. Chen is described as a new species from North Taiwan. This new species with a hypochnoid-floccose basidiome and nodoseseptate hyphae, belongs to the subgenus Saccoblastia Lowy. Helicogloea globispora is allied to $H$. sphaerospora (A. Möller) Lowy, which has smaller basidiospores.

Key words: Helicogloea globispora, new species, Saccoblastia, Taiwan

Sheng-Hua Wu, Department of Botany, National Museum of Natural Science, Taichung, Taiwan, ROC. E-mail: shwu@nmns.edu.tw

Zuei-Ching Chen, Department of Botany, National Taiwan University, Taipei, Taiwan, ROC

\section{Introduction}

Helicogloea Pat. is a heterobasidiomyceteous genus, characterized by having resupinate basidiomes and transversely septate basidia. Baker $(1936,1946)$ accommodated species with both mucous-gelatinous and floccose basidiomes in this genus. Donk (1966) recognized the genus Saccoblastia A. Möller as having hypochnoidfloccose basidiomes and nodose-septate hyphae, while Helicogloea has mucous-gelatinous basidiomes and simple-septate hyphae. Lowy (1971) treated Saccoblastia as a subgenus of Helicogloea. The treatment of Lowy is provisionally adopted in this study. Baker (1946) recognized 11 species in Helicogloea. Hawksworth et al. (1995) recorded 16 species in Helicogloea. In ultrastructural studies, McLaughlin et al. (1988) demonstrated simple septa and spindle pole bodies based on a Helicogloea specimen. Wells (1990) established a new species, H. variabilis $\mathrm{K}$. Wells, based on studies of this specimen.

\section{Methods}

Free-hand thin sections were made with the aid of a razor blade under a dissecting microscope of $50 \times$ magni- fication. For microscopic observations, the sections were stained with $1 \%$ aqueous Phloxine in $5 \% \mathrm{KOH}$. For observing details of the microscopic features, it was necessary to press the cover slide to tease apart the hyphal structures. The drawings were made with the aid of a drawing tube attached to the microscope. The studied specimen is deposited at the herbarium of the National Museum of Natural Science, Taichung, ROC (TNM).

\section{Description of species}

Helicogloea globispora Sheng H. Wu \& Z.C. Chen, sp. nov. - Fig 1.

Basidiocarpus effusus, membranaceus, 80-150 $4 \mathrm{~m}$ crassus; superficies hymenialis plana. Hyphae fibulatae, 2-4 $\mu \mathrm{m}$ diam. Cystidia desunt. Probasidia cylindrica vel clavata, 20-55 × 3.5$8.5 \mu \mathrm{m}$. Hypobasidia cylindrica, transverse 3septata, $60-75 \times 6-9 \mu \mathrm{m}$. Basidiosporae globosae vel subglobosae, laeves, tenuitunicatae, 9-12.5 × 8.5-11.5 $\mathrm{mm}$.

Holotype: Taiwan, Taipei, Yangminshan National Park, Luchiaokenghsi Ecological Reserve, alt. $300 \mathrm{~m}$, on rotten branch of angiosperm, 23.X.1999 Wu 9910-7 (TNM F9974). 
Basidiome resupinate, white, hypochnoidfloccose, 80-150 $\mu \mathrm{m}$ thick; margin concolorous, thinning, arachnoid. Hymenial surface smooth. Subiculum with moderately loose texture; hyphae nodose-septate, colourless, horizontal near the substratum, somewhat vertical elsewhere, 2$4 \mu \mathrm{m}$ diam., thin-walled, basal hyphae slightly thick-walled. Cystidia lacking. Probasidia pleural, or terminal but usually bearing a lateral branch, subclavate or cylindrical, 20-55 × 3.5-8.5 $\mu \mathrm{m}$, usually guttulate. Hypobasidia usually pleural, cylindrical, 60-75 × 6-9 $\mu \mathrm{m}$, transversely 3septate; sterigmata subulate, up to $9 \times 2.3 \mu \mathrm{m}$. Basidiospores globose-subglobose, colourless, smooth, thin-walled, 9-12.5 $\times 8.5-11.5 \mu \mathrm{m}$, guttulate, bearing a distinct apiculus.

Etymology: "Globispora", from the globose shape of the basidiospores.

Specimen examined: See type.

Distribution: So far known only from Taiwan.

Helicogloea globispora has hypochnoidfloccose basidiomes and nodose-septate hyphae, features which correspond with the concept of the subgenus Saccoblastia. This new species is allied to $H$. sphaerospora (A. Möller) Lowy, owing to the globose basidiospores of both species. However, the latter has smaller ba- sidiospores of 6-8 $\mu \mathrm{m}$ diam., according to Möller (1895).

Acknowledgments. We are indebted to Dr. Peter Roberts, Kew, for improving the manuscript. This study was supported by the National Science Council of ROC, no. NSC 89-2311-B-178-03 to S.H. Wu, and no. NSC 892311-B-002-008 to Z.C. Chen.

\section{References}

Baker, G.E. 1936: A study of the genus Helicogloea. Ann. Missouri Bot. Gard. 23: 69-128.

Baker, G.E. 1946: Addenda to the genera Helicogloea and Physalacria. - Mycologia 8: 630-638.

Donk, M.A. 1966: Check list of European Hymenomycetous Heterobasidiae. - Persoonia 4: 145-335.

Hawksworth, D.L., Kirk, P.M., Sutton, B.C. \& Pegler, D.N. 1995: Ainsworth \& Bisby's Dictionary of the Fungi. -. Intern. Mycol. Inst. 616 pp

Lowy, B. 1971: Flora neotropica. Monograph No. 6. Tremellales. - Hafner Publ. Co. Inc., New York. 153 pp.

McLaughlin, D.J., Kleven, N.L. \& Boehm, E.W.A. 1988: Ultrastructural characters in Helicogloea and their significance for the phylogeny of the auriculariacous fungi. - Mycol. Soc. Amer. News lett. 39: 39:39 (Abstract).

Möller, A.1895: Protobasidiomyceten (Untersuchungen aus Brasilien). - Bot. Mitth. Trop. 8: 1-179.

Wells, K. 1990: An undescribed species of Helicogloea from Brazil. - Mycol. Res. 4: 835-839.
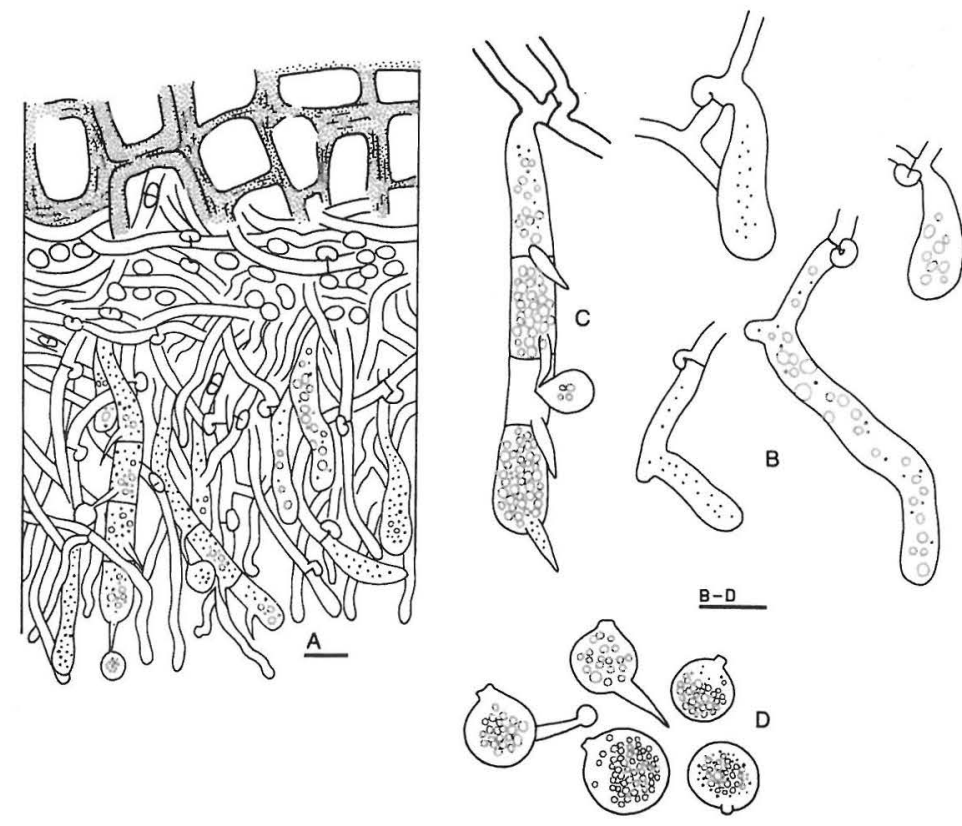

Fig. 1. Helicogloea globispora (holotype). A. Basidiome section with substratum (woody cells) at top. B. Probasidia. C. Hypobasidium. D. Basidiospores. Scale bars $=10 \mu \mathrm{m}$. 